\title{
Pengembangan Media Scrap Book Tema 4 Berbagai Pekerjaan Subtema 3 Pekerjaan Orang Tuaku
}

\author{
Sri Utaminingsih ${ }^{1}$, Ferina Agustini2 ${ }^{2}$, Moh Aniq KHB ${ }^{3}$ \\ 123 PGSD Fkultas Ilmu Pendidikan Universitas PGRI Semarang
}

\begin{abstract}
Abstrak
Pengembangan Media Scrap Book Tema 4 Berbagai Pekerjaan Subtema 3 Pekerjaan Orang Tuaku Pada Kelas IV Sekolah Dasar. Tujuan Penelitian ini untuk mengetahui kevalidan dan kepraktisan dari pengembangan media Scrap Book pada materi tema 4 berbagai pekerjaan subtema 3 pekerjaan orang tuaku kelas IV Sekolah Dasar. Jenis penelitian yang digunakan yaitu Research and Development. Model penelitian yang di gunakan Borg and Gall.Pada tahap pertama hasil rata-rata validasi media $78,33 \%$ dan rata-rata validasi materi $61,66 \%$. Tahap kedua hasil hasil rata-rata validasi media $81,66 \%$ dan rata-rata validasi materi $88,33 \%$ dan hasil respon siswa terhadap media Scrap Book di peroleh rata-rata 94,45\%. Dapat disimpulkan bahwa media Scrap Book pada materi tema 4 berbagai pekerjaan subtema 3 pekerjaan orang tuaku valid dan praktis sehingga layak digunakan sebagai media pembelajaran.
\end{abstract}

\section{Keywords:}

Pengembangan, Scrap

book, Subtema 3

Pekerjaan Orang

Tuaku

\section{PENDAHULUAN}

Pendidikan adalah suatu kegiatan yang sengaja dilakukan yang bertujuan untuk mengembangkan potensi dalam diri siswa agar memiliki pengetahuan, keterampilan, dan kecakapan sosial yang diperlukan dirinya dalam kehidupan bermasyarakat. Seperti yang telah diatur dalam Undang-Undang No. 20 Tahun 2003 pasal 3 menjelaskan bahwa tujuan pendidikan nasional adalah mengembangkan potensi dalam diri siswa agar menjadi manusia yang beriman dan bertwakwa kepada Tuhan Yang Maha Esa, berkarakter, cakap, berilmu, sehat, mandiri, kreatif, demokratis, dan bertanggung jawab. Dasar landasan UndangUndang tersebut merupakan bagian isi dan kelengkapan kurikulum untuk pencapaian tujuan pendidikan secara formal.

Kurikulum sangat penting bagi proses berlangsungnya pendidikan karena kurikulum meruapakan perencanaan yang digunakan sebagai pedoman untuk mencapai tujuan pendidikan. Saat ini pendidikan di Indonesia pada jenjang SD menggunakan kurikulum 2013 yang bersifat tematik integratif atau yang disebut dengan pembelajaran tematik. Pembelajaran tematik integratif (terpadu) dalam kurikulum 2013, pembelajaran tematik terpadu adalah pembelajaran yang dikemas dalam bentuk tema-tema berdasarkan muatan beberapa mata pelajaran yang dipadukan atau di integrasikan.Menurut Majid (2014 : 80) model pembelajaran tematik adalah model pembelajaran terpadu yang menggunakan tema untuk mengaitkan beberapa mata pelajaran sehingga dapat memberikan pengalaman bermakna kepada murid. Dikatakan bermakna karena dalam pembelajaran tematik, siswa akan memahami konsep-konsep yang mereka pelajari melalui pegalaman langsung dan menghubungkannya dengan konsep lain yang telah di pahaminya.

Pembelajaran terpadu / tematik menawarkan model-model pembelajaran yang menjadikan aktivitas pembelajaran formal maupun informal, meliputi pembelajaran inquiry secara aktif sampai dengan penyerapan pengetahuan dan fakta secara pasif, dengan memberdayakan pengetahuan dan pengalaman untuk membantunya mengerti dan memahami dunia kehidupannya. Pembelajaran terpadu berorientasi pada praktik pembelajaran yang sesuai dengan kebutuhan dan perkembangan siswa.

\footnotetext{
* Corresponding author.
} 
Pendekatan ini berangkat dari teori pembelajaran yang mengolah proses latihan / hafalan (drill) sebagai dasar pembentukan pengetahuan dan struktur intelektual anak. Teori pembelajaran ini dimotori para tokoh psikologi Gesalt, termasuk Piaget yang menekankan bahwa pembelajaran itu harsulah bermakna dan berorinetasi pada kebutuhan dan pengembangan anak. Pendekatan pembelajaran terpadu lebih menekankan pada penerapan konsep belajar sabil melakukan (learning by doing).

Fokus perhatian dalam pembelajaran tematik terletak pada proses yang ditempuh siswa saat berusaha memahami isi pembelajaran sejalan dengan bentuk-bentuk keterampilan yang harus dikembangkannya. Tema merupakan wadah atau wahana untuk mengenalkan berbagai konsep materi kepada anak didik secara menyeluruh. Tujuan dari adanya tema ini bukan hanya untuk menguasai konsep-konsep dalam suatu mata pelajaran, akan tetapi juga keterkaitanya dengan konsep-konsep dari mata pelajaran lainnya.

Namun dewasa ini tidak bisa dipungkiri bahwa materi pembelajaran tematik membuat siswa kurang menguasai keseluruhan materi. Hal ini disebabkan karena penyampaian materi setiap mata pelajaran pada pembelajaran tematik di ambil dengan skala kecil dan berkesinambungan antara mata pelajaran satu dengan mata pelajaran lainnya. Selain itu faktor penyebab pembelajaran tematik relatif susah di pahami oleh siswa karena sebagian besar guru masih menyampaikan materi pembelajaran tematik secara verbal sehingga proses pembelajaran cenderung membosankan dan siswa sulit memahami materi yang disampaikan. Oleh karena itu, perlu adanya inovasi-inovasi baru dalam menyampaikan materi pembelajaran tematik.

Salah satu inovasi yang dapat menarik perhatian sisswa dalam proses pembelajaran adalah dengan menggunakan media yang kreatif dan inovatif. Menurut Kustandi (2016 : 8), media pembelajaran adalah alat yang dapat membantu proses belajar mengajar dan berfungsi untuk memperjelas makna pesan yang disampaiakn, sehingga dapat mencapai tujuan pembelajaran yang lebih baik dan sempurna.Dengan demikian menggunakan media, proses pembelajaran akan lebih menarik. Selain itu tujuan pembelajaran akan mudah dicapai karena materi yang diajarkan oleh guru akan lebih jelas dan mudah dipahami oleh.

Terdapat beberapa manfaat dari penggunaan media pada saat kegiatan belajar mengajar. Sudjana \& Rivai dalam Arsyad (2013 : 28) mengemukakan manfaat media pembelajaran dalam proses belajar siswa : (a) pembelajaran akan lebih menarik perhatian siswa sehingga dapat menumbuhkan motivasi belajar; (b) bahan pembelajaran akan lebih jelas maknanya sehingga dapat lebih dipahami oleh siswa dan memungkinkannya menguasai dan mencapai tujuan pembelajaran; (c) metode mengajar akan lebih bervariasi, tidak semata-mata komunikasi verbal melalui penuturan kata-kata oleh guru, sehingga siswa tidak bosan dan guru tidak kehabisan tenaga, apalagi kalau guru mengajar pada setiap jam pelajaran; (d) siswa dapat lebih banyak melakukan kegiatan belajar sebab tidak hanya mendengarkan uraian guru, tetapi juga aktivitas lain seperti mengamati, melakukan , mendemonstrasikan, memerankan, dan lain-lain.

Selain itu, pertimbangan lain yang diperlakukan guru saat memilih media pembelajaran adalah kesesuaian media dengan tahapan perkembangan kognitif siswa. Merujuk pada teori perkembangan kognitif Jean Piaget, perkembangan kognitif (intelektual) individu berlangsung dalam 4 tahap, yaitu : 1) Tahap sensorimotor, tahap ini berkembang dari mulai 0 - 2 tahun. 2) Tahap praoperasional, mulai dari 2 7 tahun. 3) Tahap operasional kongkrit, tahap ini berkembang dari 7 - 11 tahun. 4) Operasi formal, yakni dimulai dari 11 tahun sampai dewasa. (Setianingsih dkk, $2018: 52-53$ ).

Siswa kelas IV sekolah dasar pada umumnya berusia 7 sampai 8 tahun. Dengan demikian, tahapan berpikir siswa kelas IV berada pada tahap perkembangan operasional kongkrit. Dalam tahapan ini, siswa belum mampu menguasai simbol verbal dan ide secara abstrak namun siswa sudah dapat berfikir logis menegnai peristiwa kongkrit serta mengelompokkan benda ke dalam bentuk yang berbeda. Oleh karena itu siswa membutuhkan kejadian dan pengalaman kongkrit dalam belajar untuk memahami suatu objek. Dengan demikian diperlukan media pembelajaran untuk mempermudah siswa memahami materi pelajaran.

Berdasarkan beberapa pertimbangan di atas, maka salah satu alternatif media yang dapat digunakan guru untuk menarik perhatian siswa dalam proses pembelajaran dan mempermudah siswa dalam memahami materi pembelajaran tematik adalah dengan menggunakan media Scrap Book (buku tempel).

Seiring perkembangan zaman, media scrap book atau yang sering disebut dengan buku tempel memiliki banyak kegunaan salah satunya dapat digunakan sebagai media pembelajaran. Scrap book berasal dari bahasa Inggris. "scrap" yang berarti siswa, potongan, atau guntingan. Sedangkan "book" berarti buku. Scrap book dapat didefinisikan sebagai seni menempel gambar atau foto pada media kertas dan menghiasnya menjadi karya kreatif. Selain berisikan gambar atau foto, scrap book juga dapat memuat potingan catatan penting yang berkaitan dengan gambar.

Melalui penggunaan media scrap book yang dikemas dalam bentuk yang menarik siswa dapat memadukan berbagai potongan gambar dan penjelasan singkat yang sesuai dengan gambar sehingga 
siswa akan lebih mudah memahami materi yang diajarkan. Selain itu, siswa dapat menajdi lebih aktif dalam proses pembelajaran.

Berdasarkan uraian latar belakang di atas, maka peneliti perlu melakukan penelitian yang berjudul “Media Scrap Book Subtema 3 Pekerjaan Orang Tuaku Pada Kelas IV Sekolah Dasar" Tujuan penulisan artikel ini adalah untuk mendeksripsikan media scrap book (buku tempel) pada subtema 3 Pekerjaan Orang Tuaku pada kelas IV sekolah dasar.

Menurut Djamarah \& Zain (2010: 120 ) kata "media” berasal dari bahasa Latin yang merupakan bentuk kata dari kata "medium", yang secara harafiah berarti "perantara atau pengantar", dengan demikian media merupakan wahana penyalur informasi belajar atau penyalur pesan. Sehingga dengan penggunaan media tersebut siswa akan merasa tertarik untuk memahami materi karena adanya rangsangan pada pikiran, perhatian, perasaan, serta minat siswa untuk mengikuti kegiatan pembelajaran. Sedangkan menurut Heinich \& kawan-kawan dalam Kustandi (2016 : 8) media sebagai perantara yang mengantar informasi yang bertujuan pembelajaran. Kustandi (2016: 8) menjelaskan bahwa media pembelajaran adalah alat yang dapat membantu proses belajar menagjar dan berfungsi untuk memperjelas makan pesan yang disampaikan, sehingga dapat mencapai tujuan pembelajaran yang lebih baik dan sempurna.Berdasarkan berbagai pendapat di atas, dapat disimpulkan bahwa media pembelajaran adalah alat bantu perantara atau penyalur informasi yang digunakan guru kepada siswa dalam proses belajar mengajar agar tercapai tujuan pembelajaran yang lebih baik.

Dalam bahasa Inggris scrap book berasal dari kata "scrap" yang artinya siswa, potongan, atau guntingan, dan "book" yang artinya buku. Menurut Lia (2014 : ii) mengatakan bahwa scrapbook adalah suatu seni merangkai foto atau memorabilia yang sering dikaitkan dengan suatu kejadian atau momen spesial. Diantaranya adalah momen kelahiran, pernikahan, kelulusan, persahabatn, dan travelling. Selain itu, John Poole (dalam Hardiana, 2015 : iii) menyatakan bahwa buku tempel atau yang dikenal dengan nama scrap book adalah sekumpulan memorabilia, foto, catatan, cerita, naarsi, puisi, quote, kliping, tiket, bon pemabyaran, dan lain sebagainya yang di rangkai dan disusun dalam sebuah album atau hand-made book . Menurut Hardiana (2015 : ii) meskipun namanya "scrap" atau sisa, namun kini bahan pembuatan scrap book semakin berkembang. Bahan-bahan tersebut tidak selalu menggunakan bahan bekas, tetapi kini telah tersedia bahan khusus untuk membuat scrapbook. Berdasarkan beberapa pendapat diatas, disimpulkan bahwa scrap book adalah media dua dimensi yang berbentuk sebuah buku dengan tema tertentu yang terdiri dari memoribilia, foto, gambar catatan, kliping quote, dan lain-lain yang dirangkai menjadi sebuah karya kreatif hand made atau buatan tangan menggunakan teknik menempel.

Terdapat beberapa karateristik scrap book yang dapat digunakan sebagai media pembelajaran, yaitu (a) berbentuk buku, (b) tema harus sesuai denagn tujuan pembelajaran, (c) data yang dimasukkan dalam scrap book harus fokus pada pokok pembahasan atau materi yang diajarkan, (d) tidak terlalu banyak hiasan, kaena tujuan utamanya adalah seabgai media pembelajaran. Dari beberapa karateristik scrap book di atas maka diharapkan dapat menjadi gambaran atau acuan dalam pembuatan media scrap book agar sesuai dengan tujuan pemanfaatan media yang sesuai dengan tujuan pembelajaran.

Terdapat beberapa kelebihan dari media scrap book yaitu, (a) menarik, media scrap book berabgai foto, gambar, catatan penting, dan lain sebagainya dengan beberapa hiasan. Sehingga tampilannya akan terlihat indah dan menarik. (b) bersifat realistik dalam menunjukkan pokok pembahasan, dengan scrap book, kita dapat menyajikan sebuah objek yang terlihat nyata melalui gambar atau foto. Karena gambar atau foto dapat memberikan detail dalam bentuk gambar apa adanya, dengan demikian kita dapat lebih mudah mengetahui dan mengingatnya dengan lebih baik. (c) dapat mengatasi keterbatasan waktu dan ruang, media scrap book dapat menjadi salah satu solusi mengenai banyaknya peristiwaatau ibjek yang sulit disajikan secara langsung dan sulit diulang. (d) mudah dibuat, cara pembuatan scrap book tidaklah sulit. Kita hanya perlu menyusun dan memadupadankan antara gambar, catatan, dan haisan sedemikianrupa. Sehingga anak-anak maupun orang dewasa akan mampu membuat scrap book sendiri. (e) bahan yang digunakan untuk membuat scrap book mudah di dapatkan. Bahan-bahan yang diperlukan dalam pembautan scrap book mudah di dapatkan. Karena kita bisa menggunakan barang-barang yang tidak terpakai atau abrang bekas. Bahkan saat ini sudah tersedia bahan khusus untuk membuat scrap book. (f) Dapat dibuat atau didesain sesuai keinginan pembuatnya. Msalnya gambar, foto, catatan, warna, tulisan, dan lain sebagainya.

Sedangkan beberapa kelemahan scrap book yaitu, (a) waktu yang digunakan relatif lama untuk membuat scrap book, waktu yang dibutuhkan dalam pembuatan scrap book relatif alama tergantung dari kerumitan penyusunannya. Semakin rumit rancangan dan penyusunan media scrap book maka waktu yang dibutuhkan relatif alma. (b) gambar yang kompleks kurang efektif dalam kegiatan pembelajaran, penggunaan gamba yang terlalu kompleks dan berlebihan akan berdampak pada kurangnya pemusatan perhatian pada pokok bahasan (materi) sehingga kegiatan pembelajaran tidaka kan berlangsung secara efektif. Dari beberapa kelemahan yang telah disebutkan di atas maka ada beberapa solusi untuk 
meminimalisir kekuarangan media scrap book yaitu desain dan susun scrap book dengan tidak terlalu rumit namun tteap terlihat menarik dan pergunakan gambar-gambar seperlunya yang sesuai dengan pokok bahasan (materi) tanpa mengguankan hiasan yang berlebihan.

Seiring perkembangan zaman fungsi scrap book tidak hanya sebagai media untuk mempercantik album foto atau gambar. Namun, kini scrap book dapat digunakan sebagai, (a) Mahar pernikahan, kini scrap book dapat menjadi pilihan yang dapat digunakan sebagai mahar pernikahan karena scrap book merupakan karya yang kreatif dan inovatif yang dapat dijadikan kenang-kenangan saat moment spesial. (b) Hobi, scrap book merupakan karya yang unik dan menarik. Sehingga, tanpa disadari akan mampu memikat sebagian orang untuk membuat atau mengoleksi scrap book sebagai hobi barunya. (c) Hadiah, scrap book dapat menjadi salah satu pilihan sebagai ahdiah ulang tahun, anniversary, pernikahan, kelahiran, dan sebagainya. Scrap book dapat dibuat secara handmade (buatan tangan) sehingga dapat disesuaikan dengan keinginan pembuatnya. (d) Media pembelajaran, kini perkembangan media pembelajaran semakin beranekaragam. Tidak semua media pembelajaran diperoleh dari toko. Namun, media pembelajaran dapat dibuat dari benda-benda yang mudah dijumpai dilingkungan sekitar. Seperti halnya scrap book yang dapat dibuat dari benda-benda di lingkungan sekitar, akan dapat digunakan sebagai media pembelajaran jika disusun denagn kreatif dan menarik serta dilengkapi gambar maupun materi yanga kan diajarkan.

Pengertian pembelajaran tematik integratif (terpadu) dalam kurikulum 2013, pembelajaran tematik terpadu adalah pembelajaran yang dikemas dalam bentuk tema-tema berdasarkan muatan beberapa mata pelajaran yang dipadukan atau diintegrasikan. Majid (2014 : 80) mengatakan bahwa model pembelajaran tematik adalah model pembelajaran terpadu yang menggunakan tema utnuk mengaitkan beberapa mata pelajaran sehingga dapat memberikan pengalaman bermakna kepada murid. Dapat di peroleh kesimpulan dari beberapa pengertian pembelajaran tematik di atas bahwa pembelajaran tematik adalah pembelajaran terpadu yang menggunakan suatu tema dengan mengaitkan beberapa mata pelajran untuk mencari dan menemukan konsep yang baru sehingga akan diperoleh pengalaman yang bermakna.

Tema Berbagai Pekerjaan memiliki 4 subtema di dalamnya, yang mana salah satunya subtema 3 yakni Pekerjaan Orang Tuaku. Melalui tema ini siswa diharapkan dapat menegtahui berbagai jenis pekerjaan baik pekerjaan orang tua dan orang yang berada di sekitarnya. Selain itu, siswa dapat mengetahui pekerjaan yang dimiliki oleh berbagai macam profesi pekerjaan sesuai dengan bidang pekerjaan masing-masing.

\section{METODE PENELITIAN}

Jenis penelitian yang digunakan adalah penelitian dan pengembangan atau Reseacrh and Development (RnD) . Menurut Richey and Kelin dalam Sugiyono (2017 : 28 - 29) perancangan dan penelitian pengembangaan adalah kajian yang sistematis tentang bagaimana membuat rancangan suatu produk, mengembangkan / memproduksi rancangan tersebut, dan mengevaluasi kinerja produk tersebut, dengan tujuan dapat diperoleh data yang empiris yang dapat digunakan sebagai dasar untuk membuat produk, alat-alat dan model yang dapat digunakan dalam pembelajaran atau non pembelajaran. Pada penelitian ini, mengacu pada model penelitian dan pengembangan (RnD) menurut Borg and Gall yang terdiri dari beberapa langkah yakni pengumpulan data, perencanaan, pengembangan draf produk, uji coba lapangan awal, revisi uji coba, uji coba lapangan, penyempurnaan produk, uji pelaksanaan lapangan, penyempurnaan, desiminasi dan implementasi.

Subyek penelitian penelitian adalah siswa kelas IV di SDN Wonolopo 02 Mijen. Pada pengembangan media Scrap Book tema 4 berbagai pekerjaan subtema 3 pekerjaan orang tuaku yang dijadiakn subjek uji coba adalah ahli media dan ahli materi yang terdiri dari dosen Universitas PGRI Semarang . Data yang dikumpulkan mengenai pengembangan media Scrap Book berupa data kualitatif dan kuantitatif.

Metode pengumpulan data yang digunakan dalam penelitian pengembangan media Scrap Book tema 4 berbagai pekerjaan subtema 3 pekerjaan orang tuaku adalah sebagai berikut.

Wawancara, dilakukan dengan guru kelas IV yang bertujuan untuk mengetahui permasalahan yang ada disekolah dasar.

Metode angket dengan memberikan tanda Check List, ditujukan untuk menguji validitas perangkat pembelajaran, terhadap pembelajaran dengan media Scrap Book yang telah dikembangkan pada angket validasi media, angket validasi materi dengan menggunakan skala Likert, sedangkan angket respon siswa menggunakan skala Guttman. 
Metode tes,tes evaluasi kelas IV pada materi tema 4 berbagai pekerjaan subtema 3 pekerjaan orang tuaku ini digunakan untuk mengetahui sejauh mana hasil belajar siswa. Tes ini ebrupa berupa soal pilihan ganda 20 butir. Tes ini dilakukan untuk pencapaian nilai kognitif.

Media dikatakan valid dan praktis jika presentase tiap item berada pada rentang $81 \%-100 \%$ dengan kriteria "baik sekali", rentang 61\% - 80\% denagn kriteria "baik" atau rentang 41\% -60\% dengan kriteria cukup.

\section{ANALISIS DAN PEMBAHASAN}

Tahap pertama yaitu melakukan studi pendahuluan melalui observasi, wawancara dan angket terhadap guru kelas IV SDN Wonolopo 02 Mijen tujuannya untuk menemukan permasalahan terkait dengan pembelajaran. Permasalahan yang ditemukan, selanjutnya dianalisis kompetensi inti, kompetensi dasar, serta indikator yang dikembangkan dari kompetensi dasar. Hasil analisis kemudian digunakan peneliti untuk perancangan desain.

Tahap selanjutnya yaitu pengembangan draf produk atau perancangan media Scrap Boook tema 4 berbagai pekerjaan subtema 3 pekerjaan orang tuaku dengan cara merancang sebuah pembelajaran disertai dengan adanya penggunaan media pembelajaran yang diharapkan dapat menunjang guru dalam menyampaikan materi sehingga diharpkan siswa dapat ikut berpartisipasi aktif dalam mengikuti kegiatan pembelajaran.

Tahap berikutnya yakni uji validator ahli media dan ahli materi . Berdasarkan hasil penilaian oleh ahli media dan ahli materi maka akan dilakukan perbaikan berdasarkan saran dan komentar yang diberikan oleh ahli media pembelajaran maupun ahli materi pembelajaran.

Hasil validasi media pembelajaran diperoleh data sebagai berikut : (1) validasi ahli media pembelajaran pertama yaitu diperoleh prosentase 78,33\% dengan kriteria baik dan layak di uji cobakan namun perlu dilakukan revisi, tahap kedua didapatkan prosentase 81,66\% dengan kriteria baik sekali dan sudah layak di uji cobakan, (2) validasi ahli materi tahap pertana yaitu diperoleh prosentase $61,66 \%$ dengan kriteria baik dan layak di uji cobakan namun perlu direvisi, tahap kedua didapatkan prosentase 88,33\% denagn kriteria baik sekali dan sudah layak di uji cobakan

Dari hasil perhitungan uji coba yang dilakukan di SDN Wonolopo 02 Mijen dengan jumlah 37 siswa. Hasil angket respon siswa terhadap media Scrap Book di SDN Wonolopo 02 Mijen didapatkan rata-rata prosentase sebesar $94,45 \%$. Setelah dikonversikan, presentase tersebut berada pada kualifikasi baik sekali.

Selain dari angket respon siswa peneliti juga melakukan tes evaluasi, yang di dapatkan nilai terendah sebesar 65 sedangakn nilai tertinggi sebesar 100 dengan jumlah soa; 20 butir soal, sedangkan nilai rata-rata siswa 90,54. Pada hasil tes evaluasi menunjukkkan 1 siswa tidak lulus KKM. Sehingga prosentase rata-rata keberhasilan media mencapai $99 \%$.

Berdasarkan hasil penelitian kompetensi pengetahuan pada rata-rata tes evaluasi terdapat peningkatan sehingga dapat dinyatakan bahwa media Scrap Book tema 4 berabgai jenis pekerjaan subtema 3 pekerjaan orang tuaku efektif dan layak untuk digunakan sebagai pendukung kompetensi berimbang siswa kelas IV sekolah dasarpada mata pelajaran tema 4 berbagai pekerjaan subtema 3 pekerjaan orang tuaku.

\section{KESIMPULAN}

Berdasarkan penelitian yang telah dilaksanakan, simpulan yang dapat peneliti berikan pada penelitian dan pengembangan media Scrap Book tema 4 berbagai pekerjaan subtema 3 pekerjaan orang tuaku adalah sebagai berikut :

Pengembangan media Scrap Book pada tema 4 berbagai pekerjaan subtema 3 pekerjaan orang tuaku untuk siswa kelas IV sekolah dasar menggunakan model Borg and Gall , yang dapat dijelaskan sebagai berikut : (1) Studi pendahuluan, tahap ini mencakup analisis kebutuhan atau permasalahan yang ada di sekolah , (2) Pemecahan masalah, tahap ini mencakup penyusunan pemecahan masalah , (3) Pengembangan draf produk, perancangan media scrap book beserta langkah-langkah penggunaannya,(4) Uji validitas oleh ahli materi dan media, dilakukan uji validitas atau penilaian oleh ahli media dan materi , (5) Uji coba, melakukan uji coba media Scrap Book pada pembelajaran dikelas. (6) Produk final, tahap final pengembangan media dan layak digunakan untuk pembelajaran dikelas.

Media Scrap Book valid digunakan sebagai media pembelajaran tema 4 berbagai pekerjaan subtema 3 pekerjaan orang tuaku untuk siswa kelas IV Sekolah Dasar yang dilakukan dengan cara melakukan validasi media pembelajaran dan validasi materi pembelajaran. Penilaian akhir ahli media pembelajaran di dapatkan prosentase $81,66 \%$ dan materi pembelajaran di dapatkan prosentase $88,33 \%$. 
Kepraktisan produk dilakukan dengan cara memberiakn angket respon siswa terhadap media Scrap Book kepada siswa kelas IV SDN Wonolopo 02 Mijen berdasarkan angket yang diberikan diperoleh rata-rata prosentase keseluruhan sebesar $94,45 \%$ dengan kriteria baik sekali. Berdasarkan hasil yang diperoleh menyatakan bahwa media Scrap Book tema 4 berbagai pekerjaan subtema 3 pekerjaan orang tuaku layak digunakan sebagai media pembelajaran tematik di kelas IV Sekolah Dasar.

\section{DAFTAR PUSTAKA}

Alfiah, A.N., Putra, N.M.D. and Subali, B., 2018. Media Scrapbook Sebagai Jurnal Refleksi untuk Meningkatkan Kemampuan Kognitif dan Regulasi Diri. Jurnal Pendidikan (Teori dan Praktik), 3(1), pp.57-67.

Aisyah, P.D. 2017. Keefektifan Penggunaan Media Scrapbook terhadap Kemampuan Menulis Hanzi Siswa Kelas X IPA SMA NU 1 Model Sungelebak Lamongan TP 2017/2018. E-journal Unesa. file:///E:/BISMILLAH/JURNAL/Aisyah.pdf. Diunduh pada 30 September 2018.

Arikunto,Suharsismi.2010.Prosedur Penelitian Suatu Pendekatan Praktik.Jakarta:Rineka Cipta

Arsyad, A. 2014. Media Pembelajaran. Jakarta: Rajawali Pers.

Damayanti. 2007. Pengaruh Media Scrap Book (Buku Tempel) Terhadap Hasil Belajar Siswa Materi Keragaman Rumah Adat di Indonesia Kelas IV Sekolah Dasar. Surabaya: PGSD FIP Universitas Negeri Surabaya. Jurnal. Volume 05 Nomor 03 Tahun 2017. Diunduh pada 30 September 2018.

Dewi, T.K. and Yuliana, R., 2018. PENGEMBANGAN MEDIA PEMBELAJARAN SCRAPBOOK MATERI KARANGAN DESKRIPSI MATA PELAJARAN BAHASA INDONESIA KELAS III SEKOLAH DASAR. Refleksi Edukatika: Jurnal Ilmiah Kependidikan, 9(1).

Djamarah, S.B dan Zain, A. 2006. Strategi Belajar Mengajar. Jakarta: PT Rineka Cipta.

Hardiana, I. 2015 . Terampil Membuat 42 Kreasi Mahar Scrapbook. Jakarta : PT Gramedia Pustaka Utama.

Kadir, A. dan Asrohah, H. 2015. Pembelajaran Tematik. Jakarta: Rajawali Pers.

Lia, R. 2014. Mahar Scrap Book Kreasi Mahar Unik dengan Tema Menarik ala Scrapbook. Surabaya : PT Trubus Agrisarana.

Majid, A. 2014. Pembelajaran Tematik Terpadu. Bandung: PT Remaja Rosdakarya.

Prahmana, R.C.I 2017. Design Research (Teori dan Implementasinya: Suatu Pengantar). Depok: PT Raja Grafindo Persada.

Puspitasari, N., Purnamasari, I. and Saputra, H.J., 2018. Keefektifan Media Scrapbook Melalui Model Student Teams Achievement Division Terhadap Motivasi Dan Hasil Belajar IPS. International Journal of Elementary Education, 2(4).

Putra, Nusa. 2015 . Research \& Development. Jakarta : PT Rajafindo Persanda.

Safitri, R.H. 2017. Pengaruh Media ScrapbookTerhadap Hasil Belajar Siswa Materi Proses Daur Air di Sekolah Dasar. Surabaya : PGSD FIP Universitas Negeri Surabaya. Jurnal. Volume 05 Nomor 03 Tahun 2017. Diunduh pada 14 Oktober 2018.

Sardiman, A.M . 2016 . Interaksi dan Motivasi Belajar-Mengajar . Jakarta : Rajawali Pers.

Setianingsih, Baedowi dkk. 2018. Perkembangan Peserta Didik. Semarang: PGSD FIP Universitas PGRI Semarang.

Slameto. 2010. Belajar \& Faktor-Faktor yang Mempengaruhinya. Jakarta: PT Rineka Cipta.

Sugiyono . 2014 . Metode Penelitian Kuantitatif, Kualitatif, dan R\&D . Bandung : Alfabeta.

. 2015 . Metode Penelitian Pendidikan : Kuantitatif, Kualitatif, R\&D. Bandung : Alfabeta.

.2017. Metode Penelitian \& Pengembangan Reseach and Development. Bandung: Penerbit Alfabeta. 
Sukmadinata, Nana Syaodih. 2015. Metode Penelitian Pendidikan. Bandung : PT Remaja Rosdakarya.

Suyono dan Hariyanto. 2015. Belajar dan Pembelajaran. Bandung: PT Remaja Rosdakarya.

Wardhani, S.W . 2018. Pengembangan Media Scrapbook Pada Materi Pengelompokan Hewan Untuk Siswa Kelas III Sekolah Dasar. Semarang : Universitas PGRI Semarang. Jurnal . Volume 2 (2) Maret 2018. Diunduh pada 19 September 2018.

Undang-undang Republik Indonesia, No. 20 Tahun 2003 tentang Sistem Pendidikan Nasional. 